\title{
Exports, Imports and Productivity: Results from Indonesian Establishment Data•
}

\author{
Fredrik Sjöholm \\ Working Paper Series in Economics and Finance No. 183 \\ August 1997
}
Stockholm School of Economics
P.O.Box 6501
S-113 83 Stockholm
Sweden

Phone: +4687369365

Fax: +468313017

Email: japfs@hhs.se

\begin{abstract}
:
Using detailed micro data from the Indonesian manufacturing sector; we examine whether participation in international trade affects establishments' productivity. Establishments participating in exports or imports have relatively high levels of productivity. Furthermore, the results suggest that establishments engaged in exports have shown comparable high productivity growth. The larger the share of an establishment's output that is exported the higher its productivity growth. The results concerning the effect of imports on productivity growth are mixed.
\end{abstract}

Keywords: Indonesia; Growth; Industry; Trade

JEL classification: F10; O12 


\section{Introduction}

There is a general belief among many economists, that participation in international trade increases productivity. For a long time the available theoretical framework predicted that increases in exports would increase productivity levels. Increases in exports, it was argued, increased the level of productivity through, for instance, utilization of scale economies. Recent theoretical work suggests that trade may increase not only the level of productivity but also the growth rate through its effects on technology. ${ }^{1}$ There are several aspects of international trade, which lead to technological change and thereby to an increased rate of economic growth. The mechanisms by which technological change is achieved can be divided into three: increased competitive pressure, embodiment in imports and knowledge transfer through commercial contacts.

Increased competitive pressure will follow from participation in international trade. Firms will have to compete with foreign firms in the domestic market and exporting firms will, accordingly, face competition from foreign firms on the international market. The increased competitive pressure that this creates will force domestic firms to adopt new technology and to increase their efficiency.

Secondly, technology is embodied in goods and therefore transferred in international trade. As the bulk of $\mathrm{R} \& \mathrm{D}$ are oriented towards the creation and improvement of new products, spillovers from improved input goods are presumably of great importance. ${ }^{2}$ Since R\&D is mostly carried on outside developing countries, productivity gains in developing countries from imports of input goods may be especially high. In other words, imports are one channel through which countries and establishments can benefit from foreign R\&D.

Finally, technology is transferred through personal commercial contacts. The reason for a positive connection between international trade and knowledge transfer is that such a transfer is made much easier by personal contacts and business dealings 
promote personal contacts. Face-to-face communication facilitates the knowledgerecipient's understanding of the new ideas, as he can immediately secure clarification or additional information from the source. The more complex the new piece of knowledge, the more important the personal contact, if the recipient is to be able to interpret it successfully. ${ }^{3}$ In trading on the world market, there is an added opportunity to "hook up" to the world's vast agglomeration of knowledge pertaining to such different matters as production-methods, corporate organization, distribution of products, etc. ${ }^{4}$

A number of cross-country studies have examined the effect of growth in exports on growth in aggregated national productivity. ${ }^{5}$ Most studies find a positive growth effect from export expansion but some objections have been raised. For instance, the causality between growth in exports and growth in productivity are ambiguous. ${ }^{6}$ Moreover, studies using time-series data have not established any positive effect on productivity growth from growth in exports. ${ }^{7}$

Another group of studies examines the connection between economic openness and economic growth. ${ }^{8}$ Openness is measured by, for instance, calculating imports and exports as a share of GDP, or by real exchange-rate distortions. These studies examine growth of GDP, but since many of them include investment and sometimes population growth in the regressions, they bear a strong resemblance to the productivity studies. Studies on openness and economic growth generally find a growth enhancing effect from openness. Levine and Renelt (1992), however, find the positive growth effect from openness to be fragile, i.e. dependent on the choice of variables included in the econometric estimation.

The question of whether participation in international trade increases growth therefore remains unanswered. One explanation could be that the level of aggregation in cross-country studies is too high to capture the effect of international trade on productivity. ${ }^{9}$ It might be more appropriate to examine the effect of international trade on productivity at a micro level rather than at a country or industry level. Moreover, by examining cross-sectional data in one specific country, one would avoid the problem of 
influences on productivity growth from e.g. differences in countries' economic policies. Such problems may have influenced the results from previous studies conducted at an aggregated country level.

We contribute to the existing literature by examining the effect of international trade on productivity at a micro level using a unique unpublished Indonesian data set of establishment data. As we have said previously, we hope to avoid some of the problems with cross-country differences in e.g. countries' macro economic policies that may have affected the results of previous studies. ${ }^{10}$ In line with new theories on international trade and economic growth, our main focus will be on examining the connection between the level of international trade and productivity growth. Additionally, we follow previous micro level studies and examine the connection between levels of international trade and levels of productivity. We examine the effect on productivity of not only exports, but also imports. New theoretical results suggest knowledge transfers through both imports and exports increase productivity, but imports have, in general, been left out of empirical studies. ${ }^{11}$ One exception is Blomström et al (1994) who examine growth in real per capita income from imports of capital equipment in 78 developing countries. Imports had no effect. Levine and Renelt (1992) use either exports or imports as a share of GDP to measure the degree of openness, but they do not include both measures simultaneously in their regressions which prevents a direct comparison of their effects. It seems that the two measures are very highly correlated in the Levine and Renelt sample of countries, since their respective coefficients are of equal size. Again, this could depend on the use of aggregated cross-country data, since countries' imports and exports are likely to be highly correlated. Hopefully, we will be able to avoid this problem by using more disaggregated data.

The results from the econometric estimations show establishments participating in exports or imports to have relatively high levels of productivity. Establishments participating in exports have also shown a comparable high productivity growth. There 
are some indications of a positive growth effect from imports, but the result is fragile to changes in the specification of the variables and test equation.

This paper is organized as follows. In part two we describe the data and present our empirical models. In part three we show the results from the econometric estimations. Finally, part four presents a summary and concluding remarks.

\section{Data and Model}

Data

The empirical analyses are based on industrial data supplied by the Indonesian Central Bureau of Statistics (Biro Pusat Statistik). Their industrial survey is conducted annually and covers all Indonesian establishments with more than 20 employees. An establishment is, in Indonesian data, a plant rather than a firm. ${ }^{12}$ In the 1991 industrial survey, the response rate was 85 percent. Data for two years - 1980 and 1991 - were supplied. Our sample of domestically owned establishments consists of 7.762 establishments in 1980 and 15.709 establishments in 1991. Furthermore, figures for 2.892 domestic establishments are available for both 1980 and 1991. This group is used in our growth estimations.

The effect of international trade on productivity is examined using figures on the establishments' total exports and imports of intermediate products. One might expect that there are more technology transfer connected with imports of capital equipment than with imports of intermediate inputs. Unfortunately, data availability, or rather its lack, restricts us to using only figures for imports of intermediate inputs.

Figures on the sectors' share of total Indonesian manufacturing exports, the share of the sector's gross output exported and imports of intermediate products as a share of gross output are shown in Table 1. 
Table 1. Industry characteristics in Indonesian Manufacturing sectors (all variables are in percent).

\begin{tabular}{|c|c|c|c|c|c|}
\hline Sector & ISIC & $\begin{array}{l}\text { Sector's } \\
\text { share of } \\
\text { total } \\
\text { Indonesian } \\
\text { manufact. } \\
\text { exports } \\
1991\end{array}$ & $\begin{array}{l}\text { Sector's } \\
\text { export as a } \\
\text { share of the } \\
\text { sector's } \\
\text { gross } \\
\text { output } \\
1991\end{array}$ & $\begin{array}{l}\begin{array}{l}\text { Sector } \\
\text { interm } \\
\text { of the } \\
\text { output }\end{array} \\
1980\end{array}$ & $\begin{array}{l}\text { pports of } \\
\text { tes as a share } \\
\text { r's gross }\end{array}$ \\
\hline All sectors & & 100.0 & 22.1 & 21.7 & 18.2 \\
\hline Food products & $311 / 12$ & 9.8 & 14.9 & 17.7 & 7.1 \\
\hline Beverages & 313 & 0.6 & 20.2 & 7.4 & 3.7 \\
\hline Tobacco products & 314 & 1.8 & 5.8 & 5.6 & 3.0 \\
\hline Textiles & 321 & 8.0 & 14.4 & 23.3 & 17.8 \\
\hline Clothing & 322 & 7.4 & 50.1 & 30.4 & 19.4 \\
\hline Leather products & 323 & 1.1 & 43.3 & 3.7 & 9.0 \\
\hline Footwear & 324 & 4.2 & 60.7 & 5.0 & 30.0 \\
\hline Wood products & 331 & 33.5 & 67.8 & 1.7 & 1.7 \\
\hline Furniture & 332 & 2.7 & 54.3 & 2.1 & 1.5 \\
\hline Paper products & 341 & 4.0 & 23.3 & 38.9 & 16.2 \\
\hline Printing & 342 & 0.1 & 1.9 & 37.8 & 17.8 \\
\hline Industrial Chem. & 351 & 3.7 & 14.4 & 34.4 & 30.2 \\
\hline Other chemicals & 352 & 0.7 & 2.9 & 28.2 & 21.4 \\
\hline Coal products & 354 & 0.0 & 0.0 & 0.0 & 6.5 \\
\hline Rubber products & 355 & 7.4 & 43.5 & 6.2 & 11.8 \\
\hline Plastic products & 356 & 1.7 & 16.9 & 46.7 & 31.3 \\
\hline Pottery & 361 & 0.4 & 13.8 & 12.2 & 17.6 \\
\hline Glass products & 362 & 0.8 & 26.0 & 16.8 & 12.3 \\
\hline Cement & 363 & 0.2 & 2.0 & 8.6 & 4.8 \\
\hline Clay products & 364 & 0.0 & 0.8 & 1.1 & 26.3 \\
\hline Non-metal products & 369 & 0.2 & 15.3 & 0.0 & 18.9 \\
\hline Iron and steel & 371 & 0.7 & 2.8 & 23.8 & 33.5 \\
\hline Non-ferrous metals & 372 & 2.1 & 30.8 & 0.0 & 46.6 \\
\hline Metal products & 381 & 3.4 & 22.8 & 48.9 & 15.4 \\
\hline Machinery & 382 & 0.1 & 1.8 & 44.7 & 32.9 \\
\hline Electrical goods & 383 & 3.1 & 18.6 & 49.7 & 37.2 \\
\hline Transport equipm. & 384 & 0.7 & 2.5 & 52.9 & 49.1 \\
\hline Professional goods & 385 & 0.2 & 35.4 & 18.9 & 42.0 \\
\hline Other manufactures & 390 & 1.3 & 53.8 & 39.7 & 28.6 \\
\hline
\end{tabular}


Wood products is the largest export sector in Indonesia. One third of total Indonesian manufacturing exports consists of wood products. Food, textiles, clothing and rubber products are other big Indonesian export sectors. Some of the sectors have a larger share of gross output going for exports than for domestic use. For example, more than $50 \%$ of gross output in clothing, footwear, wood, furniture and other manufactures is exported. Imports of raw materials as a share of gross output fell slightly between 1980 to 1991 because of the large increase in domestic output. Some raw materials that had to be imported in 1980 were being produced in Indonesia by 1991. Plastics, metal products, machinery, transport equipment and electrical goods are sectors which all imported relatively large quantities of raw materials in 1980. In 1991 non-ferrous metals, professional goods and transport equipment accounted for comparable high import shares of raw materials.

\section{Empirical Models}

Our main focus in the empirical work will be on examining the effect of the level of international trade on productivity growth. We start with a simple production function with two factors of production:

$Y_{i t}=A_{i t} f\left(L_{i t}, K_{i t}\right)$,

where $Y_{i t}$ is value added in establishment $i$ at time $t$, and $A, L$ and $K$ are the level of productivity, the number of employees and the capital stock. Taking total derivatives of equation (1) and leaving out the indexes for simplicity, one gets:

$$
\dot{Y}=\dot{A}+\beta_{1} \dot{L}+\beta_{2} \dot{K}
$$


where a dot over a variable indicates its growth and where $\beta_{1}$ and $\beta_{2}$ are the elasticity of output with respect to $L$ and $K$. Since capital stocks are not available, we replace $d K$ with total investments, $I$, which enables us to write equation (2) as:

$\dot{Y}=\dot{A}+\beta_{1} \dot{L}+\alpha_{2} \frac{I}{Y}$,

where $\alpha_{2}$ is the marginal physical product of capital. ${ }^{13}$ We want to examine if exports and imports increase productivity growth. We therefore assume that productivity growth can be expressed as a function of exports and imports:

$\dot{A}=f$ (Exports, Imports).

Combining equation (4) and equation (3) we end up with our growth model:

$$
\dot{Y}=\beta_{0}+\beta_{1} \dot{L}+\alpha_{2} \frac{I}{Q}+\beta_{3} \frac{\text { Imports }}{\mathrm{Q}}+\beta_{4} \frac{\text { Exports }}{\mathrm{Q}}+e,
$$

where $Q$ is gross output, and $e$ is a residual. Growth in value added is between 1980 and 1991, i.e. growth under the entire period. All variables are in percent. We choose to calculate investment as a share of gross output rather than as a share of value added. Various measures of exports and imports will be used. Firstly, we will use dummy variables for participation in exports and imports. The dummy variables will help us to examine if participation in international trade increases productivity growth. Secondly, the endogenous growth literature stresses the importance of international trade levels for economic growth. The effect on productivity growth from the level of imports and exports will therefore be examined. One has to be careful in constructing the variables for investment and for the level of imports since there for a given level of gross output is a negative relationship between investment/imports and value added. Alternative constructions of imports and investment, as well as different specifications of equation 
5, will therefore be considered in the empirical estimations. In most estimation we use figures on investment and imports as a share of gross output from 1980. An establishment's investments and imports as a share of gross output are assumed to be constant over the period. Exports as a share of gross output are from 1991 as no export figures are available for 1980. Thus, establishment's export intensities are assumed to be constant over the period. One caveat concerning the export variable has to be made. Although economic theory suggests participation in international trade to increase growth, we can not rule out the possibility of a causal link also in the other direction; establishments experiencing high growth become exporters. We cannot address the issue of causality between exports and growth, since it requires long time series both on exports and productivity.

Our sample used in the growth estimations consists of establishments that existed in both 1980 and in 1991. One potential bias of our results could be that establishments operating in 1980 but have exit the market or establishments that have entered the market after 1980 are not in the sample. Focusing exclusively on the survivors may not be appropriate for drawing more general conclusions on the relationship between trade and productivity. An additional problem could be that we have to use the same aggregated manufacturing price deflator for all establishments. Price increases are, however, likely to vary between sectors.

In an attempt to control for the two problems mentioned above, we may follow previous micro level studies and estimate effects on the level of productivity in all Indonesian establishments using nominal prices. In addition to the growth estimations, we therefore estimate the level model:

$\frac{V A}{L}=\beta_{0}+\beta_{1} \frac{I}{L}+$ Export dummy + Import dummy + Sector dummy $+e$

Value added per employee is a function of investment per employee and of exports and imports. Value added and investment are measured in billions of Indonesian rupiahs 
and employment in number of employees. The logarithmic form of value added per employee and of investment per employee has been used. The import (export) dummy variable is given the value 1 if the establishment has any imports (exports) and zero if the establishment has no imports (exports). We have included sector specific industry dummy variables at a four-digit level of ISIC, since the level of productivity is likely to differ between sectors.

\section{Regression Results}

\section{Growth estimations}

We will estimate the linear relationship in equation 5, using ordinary least square. The results from four different estimations of equation 5 are shown in Table 2. Pre-testing revealed heteroscedasticity so all variance-covariance matrixes have been estimated using White's (1980) method.

Growth in labor and investment as a share of gross output are positive and significant in all estimations. The coefficient for growth in labor is above unity. One possible reason is that we only control for the quantity of labor and not for the quality. The coefficient is therefor likely to incorporate the effect of human capital.

In Regression 1 we include dummy variables for imports and exports. The import (export) dummy variable is given the value one if an establishment has any imports (exports) and zero if the establishment has no imports (exports). As we said previously, by using dummy variables for imports and exports we can see if establishments participating in international trade have shown comparable high productivity growth. The import dummy variable has a positive sign in regression 1 . The coefficient is not, however, statistically significant. We cannot, therefore, conclude that imports increase the growth rate. The export dummy variable is positive and highly significant. Exporting establishments have increased their growth rate with some 23 percent. 
Table 2. The effect of international trade on productivity growth. Dependent variable - growth in value added (1980-1991).

\begin{tabular}{|c|c|c|c|c|}
\hline Variables & Regression 1 (OLS) & Regression 2 (OLS) & Regression 3 (OLS) & $\begin{array}{l}\text { Regression } 4 \text { (Robust } \\
\text { Estimation) }\end{array}$ \\
\hline Constant & $\begin{array}{l}32.68 \\
(13.30)^{* * *}\end{array}$ & $\begin{array}{l}35.85 \\
(17.06)^{* * *}\end{array}$ & $\begin{array}{l}32.66 \\
(14.61)^{* * *}\end{array}$ & $\begin{array}{l}34.85 \\
(17.43)^{* * *}\end{array}$ \\
\hline$\dot{L}$ & $\begin{array}{l}1.07 \\
(28.43) * * *\end{array}$ & $\begin{array}{l}1.08 \\
(29.04)^{* * * *}\end{array}$ & $\begin{array}{l}1.08 \\
(28.83)^{* * * *}\end{array}$ & $\begin{array}{l}1.08 \\
(34.69) * * *\end{array}$ \\
\hline$I$ & 0.11 & 0.11 & 0.12 & 0.10 \\
\hline $\bar{Q}$ & $(3.14)^{* * *}$ & $(3.05)^{* * *}$ & $(3.19)^{* * *}$ & $(1.72)^{*}$ \\
\hline Import dummy & $\begin{array}{l}5.61 \\
(1.36)\end{array}$ & --- & --- & \\
\hline Export dummy & $\begin{array}{l}22.96 \\
(3.14) * * *\end{array}$ & --- & --- & \\
\hline Imports & & 0.01 & 0.35 & 0.001 \\
\hline Q & |--- & $(0.14)$ & $(3.05)^{* * *}$ & $(0.08)$ \\
\hline Exports & --- & 0.19 & 0.22 & 023 \\
\hline$Q$ & & $(1.96)^{* * *}$ & (1.48) & $(2.49)^{* *}$ \\
\hline$\left(\frac{\text { Imports }}{\mathrm{Q}}\right)^{2}$ & --- & --- & $\begin{array}{l}-0.0001 \\
(3.36)^{* * *}\end{array}$ & --- \\
\hline $\begin{array}{l}\left(\frac{\text { Exports }}{Q}\right)^{2} \\
\bar{R}^{2} \\
\text { Number of } \\
\text { observations }\end{array}$ & $\begin{array}{l}0.36 \\
2892\end{array}$ & $\begin{array}{l}0.36 \\
2892\end{array}$ & $\begin{array}{l}-0.0002 \\
(0.30) \\
\\
0.36 \\
2892\end{array}$ & $\begin{array}{l}--- \\
0.36 \\
2892\end{array}$ \\
\hline
\end{tabular}

Note: t-statistics within brackets are based on White's (1980) adjustment for heteroscedasticity. *) Significant at the 10 percent level, **) Significant at the 5 percent level, ***) Significant at the 1 percent level.

Establishments exporting some of their output were found to have shown a comparable high productivity growth in regression 1 . We continue in regression 2 by examining if the level of exports, and imports, increases productivity growth. We find exports to be both positive and statistically significant. Establishments with a ten 
percent higher export share have shown approximately two percent higher productivity growth. The level of imports is not increasing productivity growth.

In regression 3 we include the square of the level of exports and imports, in order to examine whether there is a non-linear relationship. The square of the level of exports is not statistically significant, but the square of the level of imports is negative and statistically significant. Moreover, inclusion of the squared variables makes the variable imports as a share of gross output positive and statistically significant. The result for the import variables is probably caused by their high correlation of 0.95 .

Examination of the residuals from regression 1 showed them to suffer from kurtosis. We therefore conducted a robust estimation in regression 4, using a minimum absolute deviation (MAD) procedure. This alternative estimation method does not have any major effect on the coefficients. Exports are still significant at a five percent level whereas imports are not statistically significant.

There are, naturally, a host of factors other than the ones controlled for that might affect productivity growth. Should any of these factors be highly correlated with the variables we used, our results could be biased. To examine our results' sensitivity to the inclusion of additional variables, we therefore conducted regressions 5 to 8 in which we tried to control for certain factors that might affect productivity growth. These regressions are shown in Table 3.

To examine whether differences between establishments' productivity growth rates were caused by industry-specific fixed effects rather than by e.g. exports, we included 201 dummy variables for different industries at a five-digit level of ISIC. The results are shown in regression 5. Inclusion of industry dummy variables does not change the positive and significant coefficient for exports. Imports are not significant.

Berry (1992) points to the heterogeneity of firms in developing countries where large firms are the primary exporters. If large firms in Indonesia are the only ones participating in international trade and if they have shown comparable high productivity growth, we might run the risk of drawing wrong conclusions regarding international trade and productivity growth. We therefore estimated regression 6 in 
which we included the variable Scale, measured as an establishment's gross output in 1980 in billions of Indonesian rupiahs. If large firms have shown comparable high productivity growth, we would expect a positive and significant coefficient for Scale. Scale is not statistically significant. Establishments with a large share of exports still have relatively high productivity growth, although inclusion of Scale decreases the significance level. The coefficient for imports is not statistically significant.

Table 3. The effect of international trade on productivity growth with inclusion of industry dummy variables, Scale, Effective rate of protection and the Herfindahl index. Dependent variable - growth in value added (1980-1991).

\begin{tabular}{|c|c|c|c|c|}
\hline Variables & Regression 5 & Regression 6 & Regression 7 & Regression 8 \\
\hline Constant & $\begin{array}{l}-22.3 \\
(0.54)\end{array}$ & $\begin{array}{l}35.78 \\
(17.02)^{* * * *}\end{array}$ & $\begin{array}{l}36.38 \\
(13.46) * * *\end{array}$ & $\begin{array}{l}35.38 \\
(13.46)^{* * *}\end{array}$ \\
\hline$\dot{L}$ & $\begin{array}{l}1.07 \\
(32.14)^{* * * *}\end{array}$ & $\begin{array}{l}1.08 \\
(29.06) * * *\end{array}$ & $\begin{array}{l}1.09 \\
(28.51) * * *\end{array}$ & $\begin{array}{l}1.08 \\
(29.05)^{* * * *}\end{array}$ \\
\hline I & 0.10 & 0.11 & 0.11 & 0.11 \\
\hline$Q$ & $(2.81)^{* * *}$ & $(3.05)^{* * *}$ & $(3.02)^{* * *}$ & $(3.05)^{* * *}$ \\
\hline Imports & -0.02 & 0.005 & 0.001 & 0.005 \\
\hline Q & $(1.60)$ & $(0.13)$ & $(0.04)$ & $(0.14)$ \\
\hline Exports & 020 & & ר? & $0>0$ \\
\hline$Q$ & $(2.81)^{* *}$ & $(1.95)^{*}$ & $(2.21)^{* *}$ & $(1.96)^{* * *}$ \\
\hline Industry dummy & estimated & --- & --- & --- \\
\hline Scale & --- & $\begin{array}{l}0.02 \\
(0.41)\end{array}$ & --- & --- \\
\hline $\begin{array}{l}\text { Effective rate of } \\
\text { protection }\end{array}$ & --- & --- & $\begin{array}{l}-0.000 \\
(0.03)\end{array}$ & --- \\
\hline Herfindahl & --- & --- & --- & $\begin{array}{l}8.59 \\
(0.27)\end{array}$ \\
\hline $\bar{R}^{2}$ & 0.42 & 0.36 & 0.36 & 0.36 \\
\hline Number of obs. & 2892 & 2892 & 2821 & 2892 \\
\hline
\end{tabular}

Note: t-statistics within brackets are based on White's (1980) adjustment for heteroscedasticity. ${ }^{*}$ ) Significant at the 10 percent level, **) Significant at the 5 percent level, ***) Significant at the 1 percent level.

It is possible that exports per se do not increase productivity, but the establishments with large exports are in sectors with few regulations, which creates 
high productivity growth. These sectors may, for instance, have low protection from imports or rather than hosting monopolies they are faced with high competition from many local competitors. Domestic and foreign competition may be factors causing high productivity growth. In order to examine the robustness of the coefficients when controlling for protection and market concentration, we include the variables Effective rate of protection and Herfindahl. The effective rate of protection is measured at a five-digit level of ISIC. The figures are from Fane and Phillips (1991) for the year 1987. If high protection decreases growth, we would expect a negative sign for Effective rate of protection. The Herfindahl index is used to measure the degree of concentration in different sectors at a three-digit level of ISIC, and is equal to the sum of establishments' squared shares of the industry's total gross output. The average value between 1980 and 1991 has been used. Unfortunately, we cannot control for the possibility that the same firm owns many establishments. It is likely, however, that there is a positive correspondence between the number of establishments and the number of firms in a certain sector. A high values on Herfindahl means a high concentration of an industry's gross output. If concentration decreases growth, we would expect a negative sign for Herfindahl. In regression 7 and regression 8 we see that neither Effective rate of protection nor Herfindahl have statistically significant effects on productivity growth. Moreover, the positive and significant coefficient for exports is unchanged. The import coefficient is, again, not significant.

Inspection of our variables in Table A1 in the appendix shows mean values to be reasonable but maximum values to be very high. The maximum values for imports, exports and investment are several times higher than gross output. Such high figures could be correct as establishments might export from stocks and import to stocks. Moreover, setting up a new establishment may result in investment figures higher than gross output. These extreme values could not, however, represent a long-term condition. In order to examine the sensitivity of our results to observations with extreme values we arbitrarily excluded observations where any of the variables, investment, imports or exports came to more than 100 percent of gross output. The 
results are shown in regression 9 in Table 4. The exclusion of 58 observations changes the results in some interesting respects. Most notably the coefficient for imports, which has been insignificant in all previous estimations, suddenly becomes significant at a one percent level. A ten percent increases in imports as a share of gross output has increased value added by around three percent. Excluding some of the observations also makes the investment variable insignificant and decreases the export coefficient.

Table 4. The effect of international trade on productivity growth in a reduced sample of observations. Dependent variable - growth in value added (1980-1991).

\begin{tabular}{|l|l|}
\hline Variables & Regression 9 \\
\hline Constant & 32.87 \\
$\dot{L}$ & $(14.33)$ \\
$\frac{I}{Q}$ & 1.08 \\
& $(28.13)^{* * *}$ \\
$\frac{\text { Imports }}{\mathrm{Q}}$ & 0.11 \\
& $(0.59)$ \\
$\frac{\text { Exports }}{Q}$ & 0.34 \\
$\bar{R}^{2}$ & $(2.98)^{* *}$ \\
Number of observations & 0.15 \\
\hline
\end{tabular}

Note: t-statistics within brackets are based on White's (1980) adjustment for heteroscedasticity. *) Significant at the 10 percent level, ${ }^{* *}$ ) Significant at the 5 percent level, $\left.{ }^{* *}\right)$ Significant at the 1 percent level.

One limitation of our study has been the use of investment ratio as a proxy for growth in capital stock. Instead of using investment figures from 1980, we experimented with using the average figures between 1980 and 1991 and including sector specific (at a five-digit level of ISIC) figures on energy consumption. The coefficients and significance level changed but the coefficients for imports and exports seemed to be stable. 
Finally, when we used average figures on imports instead of figures on 1980, the significance level for imports increased and the coefficient was significant at a ten percent level in most estimation.

\section{Level estimations}

The results from the level estimations are shown in Table 5. If participation in international trade increase the level of productivity, we would expect positive coefficients for the import and export dummy variables. Establishments engaged in imports or exports have comparable high productivity levels. The coefficient for imports is statistically significant in both 1980 and in 1991, and the coefficient for exports is statistically significant in 1991. The significant coefficients were stable when Effective rate of protection and Herfindahl were included. Therefore, we can conclude that establishments engaged in international trade have comparable levels of high productivity.

Table 5. Estimations on the level of productivity. Dependent variable value added per employee.

\begin{tabular}{|l|l|l|}
\hline Variables & 1980 & 1991 \\
\hline Constant & 6.10 & 7.68 \\
Investment per employee & $(19.73)^{* * *}$ & $(20.76)^{* * *}$ \\
& 0.02 & 0.02 \\
Import dummy & $(16.98)^{* * *}$ & $(24.09)^{* * *}$ \\
& 0.29 & 0.33 \\
Export dummy & $(12.11)^{* * *}$ & $(14.31)^{* * *}$ \\
& --- & 0.31 \\
Industry dummy variables & estimated & $(10.99)^{* * *}$ \\
$\bar{R}^{2}$ & & estimated \\
Number of observations & 0.31 & \\
\hline
\end{tabular}

Note: t-statistics within brackets are based on White's (1980) adjustment for heteroscedasticity. *) Significant at the 10 percent level, $* *)$ Significant at the 5 percent level, $* * *)$ Significant at the 1 percent level. 


\section{Summary and Concluding Remarks}

We have in this paper examined the effect of international trade on productivity in Indonesian manufacturing establishments. The empirical work is, admittedly, suffering from various methodological problems. Still, the issue of international trade and productivity is too important to be ignored. We address the methodological difficulties by using various constructions of the variables and of the test equation. Thereby, we reduce the risk of drawing conclusions on fragile or spurious relationships.

Some conclusions can be made from our work. Indonesian establishments exporting parts of their output have shown comparable high productivity growth. Moreover, the larger the share of output that goes in exports the higher the productivity growth. The positive effect on productivity from exports seems to be stable using various estimation procedures and choice of sample. Imports in most estimation do not affect the rate of productivity growth. This result, however, seems to be caused by a small number of observations and exclusion of these observations makes the productivity effect from the level of imports highly significant. Moreover, constructing our import variable with average figures between 1980 and 1991 does also increase the statistical significance of imports. Finally, Indonesian establishments engaged in imports as well as exports, have comparable high productivity levels.

Grossman and Helpman suggest that international trade facilitates knowledge transfers, but they do not differentiate between the effects of imports and the effects of exports. ${ }^{14}$ We found a positive productivity effect from exports whereas the effect of imports is more uncertain. It would be interesting to examine the productivity effect of total imports or of imports of capital equipment instead of being restricted to imports of intermediate products. This type of examination might reveal an increased significance level of imports. Our results may also suggest that either knowledge transfers through exports are, relatively speaking, more important than knowledge transfers through imports, or that there is some other growth-promoting effect 
connected with exports. One explanation could be the relatively high competitiveness of world markets.

\section{Appendix}

Table A1. Descriptive statistics for 2892 Indonesian manufacturing establishments.

\begin{tabular}{|l|l|l|l|l|}
\hline Variable & Mean & Standard Deviation & Minimum & Maximum \\
\hline$\dot{Y}$ & 63.0 & 131.3 & -700.2 & 1103.0 \\
$\frac{I}{Q}$ & 23.0 & 71.4 & -328.1 & 521.5 \\
$\frac{\text { Imports }}{\mathrm{Q}}$ & 9.8 & 63.8 & 0.0 & 1636.6 \\
$\frac{\text { Exports }}{Q}$ & 10.5 & 57.8 & 0.0 & 2943.3 \\
$\begin{array}{l}\text { Scale } \\
\text { Effective rate of } \\
\text { protection }\end{array}$ & 129.8 & 20.6 & 0.0 & 373.0 \\
Herfindahl & 0.1 & 25.4 & 0.002 & 996.2 \\
\hline Note: All & 5.5 & 171.2 & -37.7 & 600.0 \\
\hline
\end{tabular}

Note: All variables except Scale and Herfindahl are in percent. Scale is measured in billions of Indonesian rupiahs. 
Table A2. Partial correlation coefficients for variables included in the econometric study.

\begin{tabular}{|c|c|c|c|c|c|c|c|c|}
\hline & $\dot{Y}$ & $\dot{L}$ & $\frac{I}{\Omega}$ & Imports & Exports & Scale & ERP & Herfin. \\
\hline & & & & Q & $Q$ & & & \\
\hline$\dot{Y}$ & 1.0 & & & & & & & \\
\hline$\dot{L}$ & 0.60 & 1.0 & & & & & & \\
\hline$I$ & 0.08 & 0.04 & 1.0 & & & & & \\
\hline$Q$ & & & & & & & & \\
\hline Imports & -0.01 & -0.03 & 0.14 & 1.0 & & & & \\
\hline $\mathrm{Q}$ & & & & & & & & \\
\hline Exports & & & & & & & & \\
\hline$Q$ & 0.15 & 0.20 & 0.04 & -0.01 & 1.0 & & & \\
\hline Scale & 0.00 & -0.01 & -0.01 & 0.02 & 0.03 & 1.0 & & \\
\hline ERP & -0.01 & -0.01 & -0.01 & 0.00 & -0.05 & 0.14 & 1.0 & \\
\hline Herfindahl & -0.01 & -0.02 & -0.01 & -0.01 & -0.07 & 0.10 & 0.13 & 1.0 \\
\hline
\end{tabular}

\section{References}

Aw, B.Y and A.R. Hwang (1995), "Productivity and the Export Market: A Firm-Level Analysis", Journal of Development Economics, Vol. 47, pp. 313-332.

Balassa, B. (1985), "Export, Policy Choices, and Economic Growth in Developing Countries after the 1973 Oil Shock", Journal of Development Economics, Vol. 18, pp. 23-35.

Berry, R.A. (1992), "Firm (or plant) size in the analysis of trade and development", in: G.K. Helleiner, ed., Trade policy, industrialization, and development: New perspectives, Oxford, Clarendon Press.

Blomström, M., Lipsey, R. and Zejan, M. (1994), "What Explains the Growth of Developing Countries?" in Baumol, W., Nelson, R. and Wolff, E. eds. Convergence of Productivity: Cross-National Studies and Historical Evidence, Oxford University Press.

Dollar, D. (1992), "Outward-oriented developing countries really do grow more rapidly: Evidence from 95 LDCs 1976-1985", Economic Development and Cultural Change, Vol. 40, pp. 523-544. 
Edwards, S. (1992), "Trade Orientation, Distortions and Growth in Developing Countries", Journal of Development Economics, Vol. 39, pp. 31-57.

Fane, G. and C. Phillips (1991), "Effective Protection in Indonesia in 1987", Bulletin of Indonesian Economic Studies, Vol. 27, pp. 105-125.

Feder, G. (1983), "On Exports and Economic Growth", Journal of Development Economics, Vol. 12, pp. 59-74.

Grossman, G.M and E. Helpman (1991a), "Trade, Innovation and Growth", American Economic Review, Vol. 80, pp. 86-91.

Grossman, G.M and E. Helpman (1991b), "Trade, Knowledge Spillovers and Growth", European Economic Review, Vol. 35, pp. 517-526.

Greenaway, D. and D. Sapsford (1994), "What Does Liberalisation Do for Exports and Growth?", Weltwirtschaftliches Archiv, Vol. 130, pp. 152-174.

Harrison, A.E. (1994), "Productivity, Imperfect Competition and Trade Reform: Theory and Evidence", Journal of International Economics, Vol. 36, pp. 53-73.

Jung, W. S. and P. J Marshall (1985), "Exports, Growth and Causality in Developing Countries", Journal of Development Economics, Vol. 18, pp. 1-12.

Kavoussi, R. (1984), "Export Expansion and Economic Growth: Further Empirical Evidence", Journal of Development Economics, Vol. 14, pp. 241-250.

Klepper, S. and E. E. Leamer (1984), "Consistent sets of Estimates for Regressions with Errors in All Variables", Econometrica, Vol. 52, pp. 163-183.

Leamer, E. E. (1994), "Testing Trade Theory", in Greenaway, D. and L. A. Winters, eds., Surveys in International Trade, Oxford, Basil Blackwell.

Levine, R. and D. Renelt (1992), "A Sensitivity Analysis of Cross-Country Growth Regressions", American Economic Review, Vol. 82, pp. 942-963.

Liu, L. (1993), "Entry-Exit, Learning, and Productivity Change: Evidence from Chile", Journal of Development Economics, Vol. 42, pp. 217-242.

Moschos, D. (1989), "Export Expansion, Growth and the Level of Economic Development", Journal of Development Economics, Vol. 30, pp. 93-102.

Ram, R. (1987), "Export and Economic Growth in Developing Countries: Evidence from Time Series and Cross-Section Data", Economic Development and Cultural Change, Vol. 24, pp. 51-70.

Rivera-Batiz, L. and P. Romer (1991), "Economic Integration and Endogenous Growth", Quarterly Journal of Economics, Vol. 106, pp. 531-555. 
Rogers, E. M. and F. F. Shoemaker (1971), Communication of Innovations: A CrossCultural Approach, New York: The Free Press.

Scherer, F.M. (1984), "Using Linked Patent and R\&D Data to Measure Interindustry Technology Flows" in R\&D, Patents and Productivity, Z. Griliches ed., Chicago: University of Chicago Press.

Sjöholm, F. (1996), "International Transfer of Knowledge: The Role of International Trade and Geographic Proximity", Weltwirtschaftliches Archiv, Vol. 132, pp. 97-115.

Statistik Industri (1991), Jakarta, Biro Pusat Statistik.

Tybout, J.R. , J. de Melo and V. Corbo (1991), "The Effects of Trade Reforms on Scale and Technical Efficiency: New Evidence from Chile", Journal of International Economics, Vol. 31, pp. 231-250.

Tybout, J.R. and M.D. Westbrook (1994), "Trade Liberalization and the Dimensions of Efficiency Change in Mexican Manufacturing Industries", Journal of International Economics, Vol. 39, pp. 53-78.

Tyler, W. (1981), "Growth and Export Expansion in Developing Countries", Journal of Development Economics, Vol. 9, pp. 121-130.

White, H. (1980), "A Heteroscedasticity-Consistent Covariance Matrix Estimator and a Direct Test for Heteroscedasticity", Econometrica, Vol. 48, pp. 817-838.

Young, A. (1991), "Learning by Doing and the Dynamic Effects of International Trade", Quarterly Journal of Economics, Vol. 106, pp. 369-405.

\footnotetext{
- Remark: I thank Magnus Blomström, Yves Bourdet, Steven Globerman, Ari Kokko, Lars Nilsson and Johan Torstensson for valuable comments. Financial support from the Bank of Sweden Tercentary Foundation, the Swedish Council for Research in the Humanities and Social Science and Tore Browaldhs Foundation for Scientific Research and Education are gratefully acknowledged.

${ }^{1}$ E.g. Grossman and Helpman (1991a), Rivera-Batiz and Romer (1991) and Young (1991).

${ }^{2}$ Scherer (1984 p. 418).

${ }^{3}$ Rogers and Shoemaker (1971).

${ }^{4}$ The connection between international trade and transfer of knowledge was empirically examined in Sjöholm (1996). International trade had a positive, significant and robust effect on international knowledge flows.

5 E.g. Tyler (1981), Feder (1983), Kavoussi (1984), Balassa (1985), Ram (1987) and Moschos (1989).

6 Jung and Marshall (1985).

7 Greenaway and Sapsford (1994).

${ }^{8}$ E.g. Dollar (1992) and Edwards (1992).

${ }^{9}$ Leamer (1994 p. 91) and Aw and Hwang (1995 pp. 314-315).

${ }^{10}$ There are a few studies in related areas, which use firm level data. For instance, Aw and Hwang (1995) examine firms in the Taiwanese electronics industry. The level of productivity is found to be higher for exporting firms than for non-exporters. Moreover, a number of studies examine the effects
} 
of general trade liberalisation on firms' efficiency and productivity growth, see e.g. Tybout $e t$ al. (1991), Liu (1993), Harrison (1994), and Tybout and Westbrook (1995).

${ }^{11}$ See Grossman and Helpman (1991b) where knowledge is assumed to be transferred through trade contacts. Knowledge increases the general level of know-how and thereby the productivity of e.g. engineers and employees in research labs. The greater the degrees of trade contacts, the greater the transfer of knowledge and productivity growth.

${ }^{12}$ The Indonesian definition of an establishment is: "A production unit engaged in a certain location, keeping a business record concerning the production and cost structure, and having one person or more that bears the responsibility or the risk of that activity." (Statistik Industri 1991).

${ }^{13}$ Replacing $d K$ with $I$ is a standard procedure in empirical work on trade and growth when one is lacking data on capital stocks. See e.g. Feder (1983), Ram (1987), and Dollar (1992).

${ }^{14}$ Grossman and Helpman (1991b). 